\title{
Prevalence and risk factors to Leptospira sp. infection in dogs attended at veterinary clinics in João Pessoa, Paraíba State, Northeastern Brazil
}

\author{
Prevalência e fatores de risco da infecção por Leptospira sp. em cães atendidos em clínicas \\ veterinárias em João Pessoa, Paraíba, Nordeste do Brasil
}

\begin{abstract}
Arthur Willian de Lima BRASIL ${ }^{\mathbf{1}}$; Diego Figueiredo da $\operatorname{COSTA}^{\mathbf{1}}$; Carla Lauise Rodrigues Menezes PIMENTA ${ }^{\mathbf{1}}$; Roberta Nunes PARENTONI ${ }^{1}$; Clebert José ALVES ${ }^{1}$; Carolina de Sousa Américo Batista SANTOS ${ }^{1}$; Sérgio
\end{abstract} Santos de AZEVEDO ${ }^{1}$

${ }^{1}$ Universidade Federal de Campina Grande, Centro de Saúde e Tecnologia Rural, Patos - PB, Brazil

\begin{abstract}
This study investigated the prevalence and risk factors associated with Leptospira sp. in dogs attended at veterinary clinics in the city of João Pessoa, State of Paraíba, Northeast Brazil. A total of 384 blood samples from dogs from 34 veterinary clinics were used from April 2015 to May 2016. The serological Leptospira sp diagnosis was carried out through Microscopic Agglutination Test (MAT), using a collection of 20 pathogenic antigens and adopting a 1:100 dilution as cutoff point. An epidemiological questionnaire was applied to the animal's owners to obtain the information used in risk factors analysis. The prevalence of seropositive animals was $11.7 \%$ (45/384), with reactions for serogroups Icterohaemorrhagiae (62.3\%), Grippotyphosa (22.2\%), Canicola (13.3\%), Djasiman 2\%) and Pomona (2.2\%). The following risk factors were identified: age from 49 to 72 months (odds ratio $=2.74)$; Age $>72$ months (odds ratio $=3.22$ ); and monthly cleaning of the environment where the animals were kept (odds ratio $=10.70)$. We concluded that dogs attended at veterinary clinics in João Pessoa are exposed to Leptospira sp infection, with predominance of serogroups kept by wild or synanthropic animals, and suggest a monthly periodic environment cleaning where the animals are kept.
\end{abstract}

Keywords: Canine leptospirosis. Microscopic agglutination test. Epidemiology. Control. Risk factors.

\section{Resumo}

O presente trabalho investigou a prevalência e os fatores de risco associados à infecção por Leptospira sp. em cães atendidos em clínicas veterinárias da cidade de João Pessoa, Estado da Paraíba, Nordeste do Brasil. Foram utilizadas 384 amostras sanguíneas de cães provenientes de 34 clínicas veterinárias no período de abril de 2015 a maio de 2016 . O diagnóstico da infecção por Leptospira sp. foi realizado com o emprego reação de Soroaglutinação Microscópica (SAM), utilizando uma coleção com 20 antígenos patogênicos e adotando como ponto de corte a diluição 1:100. Foi aplicado um questionário epidemiológico aos proprietários dos animais para obtenção de dados a serem utilizados na análise de fatores de risco. A prevalência de animais soropositivos foi de 11,7\% (45/384), com reações para os sorogrupos Icterohaemorrhagiae (62,3\%), Grippotyphosa (22,2\%), Canicola (13,3\%), Djasiman (2,2\%) e Pomona (2,2\%). Foram identificados os seguintes fatores de risco: idade entre 49 e 72 meses (odds ratio $=2,74)$, idade maior que 72 meses (odds ratio $=3,22$ ), e limpeza mensal do ambiente onde os animais permanecem (odds ratio $=10,70)$. Conclui-se que cães atendidos em clínicas veterinárias de João Pessoa estão expostos à infecção por Leptospira sp., com predominância de sorogrupos mantidos por animais selvagens, e foi sugerida a realização da limpeza periódica do ambiente ocupado pelos animais.

Palavras-chave: Leptospirose canina. Soroaglutinação microscópica. Epidemiologia. Controle. Fatores de risco. 
Correspondence to:

Sérgio Santos de Azevedo

Universidade Federal de Campina Grande, Centro de Saúde e

Tecnologia Rural

Av. Universitária s/n, Santa Cecília

CEP 58700-970, Patos, PB, Brazil

e-mail: sergio.azevedo@ufcg.edu.br

Received: 07/03/2018

Approved: 07/08/2018

\section{Introduction}

The relationship between humans, animals and the environment has generated severe ecological imbalances, causing the depletion of natural resources. These environmental changes directly affect the dynamics of zoonoses, changing their forms of presentation, occurrence and pathogenicity (MWANGI et al., 2016). In this context, pets, such as dogs, which are increasingly incorporated into family nuclei as members of the family, may play a major role in the maintenance and transmission of infectious agents, besides being sentinels for the respective diseases (ULLMANN et al., 2008). In this way, diseases such as leptospirosis need to be monitored and their risks assessed in the ecosystem.

Leptospirosis is caused by bacteria of the genus Leptospira, classified according to homology of DNA in three groups: pathogenic, with 10 species; intermediates, five species; saprophytic, six species (BOURHY et al., 2014). Disease transmission occurs by direct contact of the intact or damaged skin and mucous membrane with urine, and by indirect contact with contaminated water (HAAKE; LEVETT, 2014).

Pathogenic Leptospira sp. may cause reproductive, renal and liver disorders or even unapparent infection, depending on the infecting serovar. Serovars adapted to dogs generally cause chronic infection with absence of clinical signs. However, the manifestation is generally acute and severe in infections caused by accidental serovars (ADLER; MOCTEZUMA, 2010).

Rodents are potential reservoirs of leptospires, eliminating the bacteria through their urine (FAINE et al., 1999). However, due to the closeness with human beings, dogs play an important role in transmission of leptospires, as they may harbor the agent in their kidneys, eliminating it in the urine in a continuous or intermittent form (MIOTTO et al., 2016).

Moreover, the municipality of João Pessoa reported an occurrence of 86 cases of human leptospirosis between 2007 and 2015 (MINISTÉRIO DA SAÚDE, 2017), which reinforces the need to conduct epidemiological surveys in dogs, since these animals are an important source of infection of Leptospira sp. in the urban environment. Therefore, this survey aimed to determine the prevalence of Leptospira sp. infection in dogs attended at veterinary clinics of João Pessoa, Paraíba state, Northeastern Brazil, as well as to identify risk factors associated with the infection.

\section{Materials and Methods}

\section{Ethical approval}

This experiment was approved and performed under the guidelines of Ethics Committee for Animal Protocol Use of Federal University of Campina Grande (Protocol No. 010.2016).

\section{Study area}

The survey was conducted in the municipality of João Pessoa, capital city of the State of Paraíba, which has about 720 thousand inhabitants (IBGE, 2010), distributed in 59 boroughs, and with an area of preserved Atlantic Forest in the center of the urban spot and bordered by mangroves (PARAÍBA, 2014). Its climate is humid tropical, with annual average temperatures of $23^{\circ} \mathrm{C}$ and annual rainfall rate above 1,906 mm (PEREIRA, 2014).

\section{Sampling}

The selection of the veterinary clinics was based on data from the Regional Council of Veterinary Medicine (CRMV-PB), which has informed the existence of 40 registered clinics; however, in the onthe-spot verification, four establishments had closed and in two others, the owners preferred not to 
participate. Then, 34 veterinary clinics in the municipality of João Pessoa distributed in the four zones of the city (north, south, east and west) were used. All pet owners signed the permission for the use of their responses to questions applied in the present investigation.

The minimum number of animals was determined by the formula for simple random sampling (THRUSFIELD, 2004):

$$
n=\frac{Z^{2} \mathbf{x} P(1-P)}{d^{2}} \text {, where: }
$$

$n=$ number of sampled animals

$Z=$ value of the normal distribution for the confidence level of $95 \%$

$P=$ expected prevalence of $50 \%$ (sampling maximization)

$d=$ error of $5 \%$

In total, 384 apparently healthy dogs, unvaccinated or vaccinated over six months against leptospirosis were selected. Females in the periparturient and lactation periods were excluded from the study. The collections occurred from April 2015 to May 2016. Samples were collected by venipuncture of the cephalic or jugular vein, using vacuum tubes of $5 \mathrm{~mL}$, and sera were placed into microtubes and frozen until the serologic tests were performed.

\section{Serologic diagnosis of Leptospira sp. infection}

The serologic diagnosis was performed by the microscopic agglutination technique (MAT) (GALTON et al., 1965; COLE et al., 1973), which is the test recommended by the World Organisation for Animal Health (OIE). A collection of 20 serovars of Leptospira sp. were used: Australis, Copenhageni, Bataviae, Bratislava, Canicola, Grippotyphosa, Djasiman, Pomona, Icterohaemorrhagiae, Hebdomadis, Wolffi, Autumnalis, Castellonis, Hardjo (Hardjobovis), Hardjo (Hardjoprajitno), Tarassovi, Sejroe, Guaricura, Cynopteri and Panama, provided by the Veterinary Bacteriology Laboratory of the Fluminense Federal University (UFF) and originated from the Pasteur Institute, France. Reactive samples at dilution rate 1:100 needed to be diluted twofold to determine the maximum positive dilution with $50 \%$ agglutination. The probable serogroup for each sample was the one that showed the highest titration, and the remaining agglutinations were considered crossreactions. Animals which had two or more serogroups with identical titration were positive, and considered for the prevalence calculation, although not considered for calculating the most common serogroups (OIE, 2014).

\section{Risk factor analysis}

Epidemiological questionnaires were applied to dog owners in order to obtain data to be used in the risk factor analysis. The analyzed variables and their respective categories were: educational level of the owner (illiterate, incomplete primary school, complete primary school, incomplete high school, complete high school, incomplete university degree, university degree); gender (female, male)' breed (pure-bred, crossbred); age (up to 48 months, 49 to 72 months, above 72 months); access to street (no, yes); feed (commercial food, homemade food, food scraps, raw meat); access to treated water (no, yes); reason for keeping the dog (company, guard, other); contact with dogs (no, yes); contact with bovine (no, yes); contact with equine (no, yes); contact with wild animals (no, yes); contact with cats (no, yes); contact with goats (no, yes); contact with sheep (no, yes); contact with swine (no, yes); type of housing (masonry, shacks, stilts, mud huts); environment where the animal lives (soil, cement, soil/cement); house near woodlands or agricultural areas (no, yes); regular garbage collection (no, yes); cleaning and disinfection of the environment where the animals are kept (daily, weekly/fortnightly, monthly); vaccination (no, yes); contact with flooded areas (no, yes); presence of rodents (no, yes); occurrence of abortions (no, yes); occurrence of stillbirths (no, yes), and presence of ticks (no, yes). 
An univariable exploratory analysis of the data was carried out for the selection of variables with $P \leq 0.2$ using the chi-square or Fischer exact tests. Subsequently, the significant variables passed to a multivariable analysis using the multiple logistic regression with significant level of 5\% (HOSMER; LEMESHOW, 2000). The adjustment of the final model was verified with the Hosmer and Lemeshow test, by which a value of $P \geq 0.05$ indicates a good fit. The collinearity between independent variables was verified by correlation analysis; for the variables with strong collinearity (correlation coefficient $>0.9$ ), one of the two variables was excluded from the multiple analysis according to the biological plausibility (DOHOO et al., 1997). Confounding was evaluated by the monitoring the alterations in the model's parameters $(>20 \%)$ when adding new variables. Data analyses were carried out using the SPSS 23.0 for Windows software.

\section{Results and Discussion}

Figure 1 presents the geographical distribution of the dogs attended at the veterinary clinics according to the zone. All animals were proceeding from the city of João Pessoa. Of the 384 evaluated samples 45 were seropositive, with a prevalence of $11.7 \%$. The most frequent serogroup was Icterohaemorrhagiae (62.3\%), followed by Grippotyphosa (22.2\%), Canicola (13.3\%), Djasiman (2.2\%) and Pomona (2.2\%), with antibody titers ranging from 100 to 3200 (Table 1).

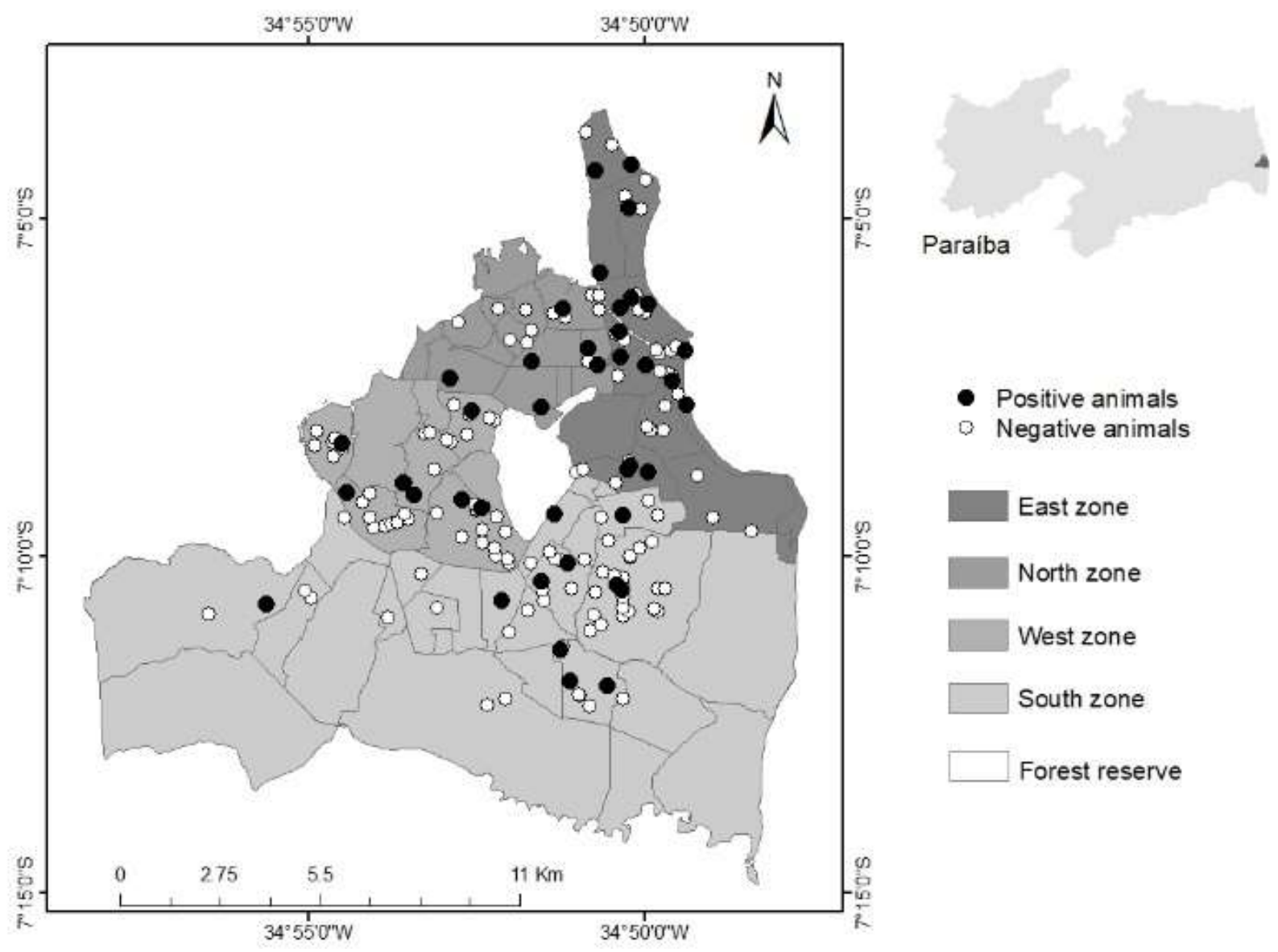

Figure 1 - Map with the division of the city of João Pessoa in zones and geographical location of the animals, according to positive and negative conditions for Leptospira sp. Infection, from April 2015 to May 2016. Detail shows the location of João Pessoa within Paraíba 
Table 1 - Leptospira sp. seropositivity in dogs attended at veterinary clinics in the municipality of João Pessoa, Paraíba, from April 2015 to May 2016 according to serogroup and respective antibody titers

\begin{tabular}{|c|c|c|c|c|c|c|c|}
\hline \multirow{2}{*}{ Serogroup } & \multicolumn{6}{|c|}{ Antibody titre } & \multirow[t]{2}{*}{ Total (\%) } \\
\hline & 100 & 200 & 400 & 800 & 1600 & 3200 & \\
\hline Icterohaemorrhagiae & 10 & 12 & 5 & 1 & 0 & 0 & $28(62.3)$ \\
\hline Grippotyphosa & 1 & 6 & 2 & 0 & 0 & 1 & $10(22.2)$ \\
\hline Canicola & 5 & 0 & 0 & 0 & 0 & 0 & $5(13.3)$ \\
\hline Djasiman & 1 & 0 & 0 & 0 & 0 & 0 & $1(2.2)$ \\
\hline Pomona & 1 & 0 & 0 & 0 & 0 & 0 & $1(2.2)$ \\
\hline Total & 18 & 18 & 7 & 1 & 0 & 1 & $45(100)$ \\
\hline
\end{tabular}

The prevalence of Leptospira sp. positive dogs attended at veterinary clinics in João Pessoa was larger than those found in Natal, Rio Grande do Norte state, where seropositivity in dogs from veterinary clinics was 6.8\% (FERNANDES et al., 2013). Other studies on the presence of anti-Leptospira sp. antibodies in domiciled and stray dogs in Paraíba state referred frequencies of $19.7 \%$ and $20.4 \%$ (BATISTA et al., 2004; AZEVEDO et al., 2011). Compared to this study, it is believed that the high frequencies observed above are related to population composition, since these studies evaluated animals from veterinary care in poor areas that did not have access to vaccination against leptospirosis, while the majority of the animals in the present study was vaccinated against leptospirosis over six months.

Dogs are accidental hosts of the Icterohaemorrhagiae serogroup and, when infected, develop signs such as high temperature, jaundice and hemorrhage that may lead to death (ELLIS, 2014). The importance of this serogroup as a cause of severe illness in humans should be highlighted. The reservoirs of this serogroup are rodents, especially Rattus norvegicus, and the occurrence of the disease is related to the high levels of rainfall and a deficit of adequate sanitary conditions (FAINE et al., 1999).

The serogroup Grippotyphosa has as its most adapted hosts wild mammals (HARTSKEERL; TERPSTRA, 1996); however, dogs may get infected with this serogroup (BATISTA et al., 2004; FERNANDES et al., 2013). The municipality of João Pessoa has a natural reserve of Atlantic Forest which extends through 23 boroughs and hosts several species of wild mammals, including rodents and marsupials (PARAÍBA, 2014), which may act as sources of infection for dogs (CORREA, 2007).

Serological reactions to serogroup Canicola has already been described in Paraíba with a frequency of 2.1\% (BATISTA et al., 2005). Dogs are maintenance hosts of this serogroup, eliminating it through the urine and acting as sources of infection for other animals and humans (KIKUTI et al., 2012; ELLIS, 2014), as well as incidental hosts for several serovars, mainly Icterohaemorrhagiae, Copenhageni, Grippotyphosa and Pomona (SUEPAUL et al., 2010; KOIZUMI et al., 2013; LOFFLER et al., 2014). In general, seroprevalence in this species is high and there is a variability in most frequent serovars, with predominance of titers against serogroups Canicola and Icterohaemorrhagiae (PINTO et al., 2017).

Serological reactions to serogroup Djasiman was found in dogs in Brazil, in the municipality of Botucatu, with frequencies of $8.7 \%$ and $2.3 \%$ (COIRO et al., 2011; LANGONI et al., 2013). This serogroup is broadly described in a great variety of wild animals (VIEIRA et al., 2016; LANGONI et al., 2016); however, it has already been isolated in a case of abortion in a bitch in Argentina (ROSSETTI et al., 2005). It should be noted that commercial vaccines for dogs in Brazil do not contemplate this serogroup, so there is no vaccine protection for the animals. In a serological study carried out in stray dogs in Paraiba, a prevalence of $17 \%$ for the serogroup Pomona (BATISTA et al., 2004 ) was observed, whereas in this survey, it was $2.2 \%$. 
Dogs are accidental hosts of this serogroup, with swine the main reservoirs (ROSSETTI et al., 2005)

The results of the univariable analysis for the risk factors with the most associated variables $(\mathrm{P} \leq 0.2)$ are presented in Table 2. In the final model of logistic regression, the identified risk factors were (Table 3): age from 49 to 72 months (odds ratio $=2.47$ ), age $>72$ months (odds ratio $=3.22$ ), and monthly cleaning of the environment where the animals are kept (odds ratio $=10.70)$. The final model presented a good fit (Hosmer and Lemeshow test: chi-square $=0.620$; degrees of freedom $=3 ; P=0.892$ ).

Table 2 - Univariable analysis of the risk factors associated with Leptospira sp. infection in dogs attended at veterinary clinics in João Pessoa, Paraíba, from April 2015 to May 2016, with variables presenting $P \leq$ 0.2

\begin{tabular}{|c|c|c|c|c|}
\hline Variables & Categories & $\begin{array}{l}\text { Total no. } \\
\text { of animals }\end{array}$ & $\begin{array}{l}\text { No. of seropositive } \\
\text { animals (\%) }\end{array}$ & $P$ \\
\hline \multirow[t]{3}{*}{ Age } & Up to 48 months & 219 & $16(7.3)$ & \\
\hline & 49 to 72 months & 63 & $9(14.3)$ & \\
\hline & $>72$ months & 102 & $20(19.6)$ & 0.005 \\
\hline \multirow{2}{*}{ Access to treated water } & No & 7 & $2(28.6)$ & \\
\hline & Yes & 377 & $43(11.4)$ & 0.193 \\
\hline \multirow{2}{*}{ Contact with bovine } & No & 375 & $42(11.2)$ & \\
\hline & Yes & 9 & $3(33.3)$ & 0.076 \\
\hline \multirow{2}{*}{ Contact with equine } & No & 375 & $42(11.2)$ & \\
\hline & Yes & 9 & $3(33.3)$ & 0.076 \\
\hline Contact with wild & No & 368 & $41(11.1)$ & \\
\hline Animals & Yes & 16 & $4(25)$ & 0.104 \\
\hline \multirow{2}{*}{ Contact with goats } & No & 377 & $42(11.1)$ & \\
\hline & Yes & 7 & $3(42.9)$ & 0.038 \\
\hline \multirow{2}{*}{ Contact with sheep } & No & 376 & $42(11.2)$ & \\
\hline & Yes & 8 & $3(37.5)$ & 0.055 \\
\hline \multirow{2}{*}{ Contact with swine } & No & 377 & $42(11.1)$ & \\
\hline & Yes & 7 & $3(42.9)$ & 0.038 \\
\hline \multirow[t]{3}{*}{$\begin{array}{l}\text { Cleaning and disinfection of the } \\
\text { environment where the animals are kept }\end{array}$} & Daily & 287 & $36(12.5)$ & \\
\hline & Weekly/fortnightly & 93 & $7(7.5)$ & \\
\hline & Monthly & 4 & $2(50)$ & 0.024 \\
\hline \multirow{2}{*}{ Vaccination } & No & 46 & $1(2.2)$ & \\
\hline & Yes & 338 & $44(13)$ & 0.028 \\
\hline \multirow{2}{*}{ Presence of ticks } & No & 174 & $27(15.5)$ & \\
\hline & Yes & 210 & $18(8.6)$ & 0.039 \\
\hline
\end{tabular}


Table 3 - Risk factors associated with leptospirosis in dogs attended at veterinary clinics of João Pessoa, Paraíba, from April 2015 to May 2016, estimated by multiple logistic regression

\begin{tabular}{|c|c|c|c|c|c|c|c|}
\hline Risk factors & $\begin{array}{l}\text { Regression } \\
\text { coefficient }\end{array}$ & $\begin{array}{c}\text { Standard } \\
\text { error }\end{array}$ & Wald & $\begin{array}{c}\text { Degrees of } \\
\text { freedom }\end{array}$ & $\begin{array}{l}\text { Odds } \\
\text { ratio }\end{array}$ & $95 \% \mathrm{CI}$ & $\boldsymbol{P}$ \\
\hline Age from 49 to 72 months & 0.906 & 0.456 & 3.941 & 1 & 2.47 & {$[1.012-6.053]$} & 0.047 \\
\hline Age $>72$ months & 1.170 & 0.373 & 9.850 & 1 & 3.22 & {$[1.552-6.688]$} & 0.002 \\
\hline $\begin{array}{l}\text { Monthly cleaning of the } \\
\text { environment where the } \\
\text { animals are kept }\end{array}$ & 2.376 & 1.114 & 4.552 & 1 & 10.70 & [1.213-95.535] & 0.033 \\
\hline
\end{tabular}

Hosmer and Lemeshow test: chi-square $=0.620$; degrees of freedom $=3 ; P=0.892$

The age groups from 48 to 72 months and $>72$ months were identified as risk factors for leptospirosis, and it has been evidenced by other authors (BATISTA et al., 2005; GHNEIM et al., 2007; ZWIJNENBERG et al., 2008; LANGONI et al., 2013). Such a fact may be explained by the greater possibility of exposure of the animals to the agent according to age. It is known that age of up to one year is a protective factor against Leptospira sp. infection, and it can be justified by the greater care that the owners have with puppies and the colostral immunity of vaccinated mothers. (LAVINSKY et al., 2012).

The cleaning of the environment only monthly was also a risk factor for leptospirosis. Inadequate sanitary conditions are a classic risk factor for urban and rural leptospirosis. With the accumulation of residues there is increase in contact with rodents, which facilitates the emergence of the infections (HAAKE; LEVETT, 2014). It is worth mentioning that the odds ratio values for this variable (10.70) may not reflect the real risk of infection, since the number of positive animals was small $(n=2)$, which contributes to the increase of the odds ratio and amplification of the confidence interval of $95 \%$.

\section{Conclusion}

This study concluded that dogs attended at veterinary clinics in João Pessoa, Paraíba state, Northeastern Brazil, are exposed to Leptospira sp. infection, with predominance of serogroups maintained by wild or synanthropic animals, and suggests the periodic cleaning of the environment where the animals are kept.

leptospirosis in stray dogs from Patos city, state of Paraíba, Brazil. Brazilian Journal of Veterinary Research and Animal Science, v. 41, n. 2, p. 131-136, 2004. doi: 10.1590/S1413-95962004000200009.

BATISTA, C. S. A.; ALVES, C. J.; AZEVEDO, S. S.; VASCONCELLOS, S. A.; MORAIS, Z. M.; CLEMENTINO, I. J.; ALVES, F. A. L.; LIMA, F. S.; ARAÚJO NETO, J. O. Seroprevalence and risk factors for leptospirosis in dogs from Campina Grande, State of Paraíba, Brazil. Arquivo Brasileiro de Medicina Veterinária e Zootecnia, v. 57, p. 179-185, 2005. Supplement 2. doi: 10.1590/S0102-09352005000800008.

BOURHY, P.; COLLET, L.; BRISSE, S.; PICARDEAU, M. Leptospira mayottensis sp. nov., a pathogenic species of the
BATISTA, C. S. A.; AZEVEDO, S. S.; ALVES, C. J.;
VASCONCELlOS, S. A.; MORAIS, Z. M.; CLEMENTINO, I. J.; LIMA, F. S.; ARAÚJO NETO, J. O. Seroprevalence of 
genus Leptospira isolated from humans. International Journal of Systematic and Evolutionary Microbiology, v. 64, n. 1, p. 4061-4067, 2014. doi: 10.1099/ijs.0.066597-0.

COIRO, C. J.; LANGONI, H.; SILVA, R. C.; ULLMANN, L. S. Risk factors to leptospirosis, leishmaniasis, neosporosis and toxoplasmosis in domiciliated and peridomiciliated dogs in Botucatu-sp. Veterinária e Zootecnia, v. 18, n. 3, p. 393-407, 2011.

COLE, J. R.; SULZER, C. R.; PURSELL, A. R. Improved microtechnique for the leptospiral microscopic agglutination test. Applied Microbiology, v. 25, n. 6, p. 976980, 1973.

CORREA, S. H. R. Leptospirose. In: CUBAS, Z. S. (Org). Tratado de animais silvestres: medicina veterinária. São Paulo: Roca, 2007. p. 736-741.

DOHOO, I. R.; DUCROT, C.; FOURICHON, C.; DONALD, A.; HURNIK, D. An overview of techniques for dealing with large numbers of independent variables in epidemiologic studies. Preventive Veterinary Medicine, v. 29, n. 3, p. 221239, 1997. doi: 10.1016/S0167-5877(96)01074-4.

ELLIS, W. A. Animal leptospirosis. In: ADLER, B. (Ed). Leptospira and leptospirosis. New York: Springer, 2014. p. 100-125.

FAINE, S.; ADLER, B.; BOLIN, C.; PEROLAT, P. Leptospira and Leptospirosis. 2. ed. Melbourne: MediSci, 1999. 272 p.

FERNANDES, A. R. F.; FERNANDES, A. G.; ARAÚJO, V. J. A.; HIGINO, S. S. S.; SILVA, M. L. C. R.; ALVES, C. J.; AZEVEDO, S. S. Seroepidemiology of canine leptospirosis in the metropolitan area of Natal, Rio Grande do Norte State. Brazilian Journal of Veterinary Research and Animal Science, v. 50, n. 3, p. 226-232, 2013. doi: 10.11606/issn.16784456.v50i3p226-232.

GALTON, M. M.; SULZER, C. R.; SANTA ROSA, C. A.; FIELDS, M. J. Application of a microtechnique to the agglutination test for leptospiral antibodies. Applied Microbiology, v. 13, n. 1, p. 81-85, 1965.

GHNEIM, G. S.; VIERS, J. H.; CHOMEL, B. B.; KASS, P. H.; DESCOLLONGES, D. A.; JOHNSON, M. L. Use of a casecontrol study and geographic information systems to determine environmental and demographic risk factors for canine leptospirosis. Veterinary Research, v. 38, n. 1, p. 37 50, 2007. doi: 10.1051/vetres:2006043.

HAAKE, D. A.; LEVETT, P. N. Leptospirosis in humans. In: ADLER, B. (Ed). Leptospira and leptospirosis. New York: Springer, 2014. p. 67-88.
HARTSKEERL, P. A.; TERPSTRA, W. J. Leptospirosis in wild animals. The Veterinary Quarterly, v. 18, p. 149-150, 1996. Supplement 3. doi: 10.1080/01652176.1996.9694722.

HOSMER, D. W.; LEMESHOW, S. Applied logistic regression. New York: John Wiley \& Sons, 2000. 397 p.

INSTITUTO BRASILEIRO DE GEOGRAFIA E ESTATISTICA (IBGE). Censo demográfico. 2010. Available from: <https://censo2010.ibge.gov.br/>. Viewed: 02 Dec. 2016.

KIKUTI, M.; LANGONI, H.; NOBREGA, D. N.; CORRÊA, A. P. F. L.; ULLMANN, L. S. Occurrence and risk factors associated with canine leptospirosis. Journal of Venomous Animals and Toxins including Tropical Diseases, v. 18, n. 1, p. 124-127, 2012. doi: 10.1590/S1678-91992012000100016.

KOIZUMI, N.; MUTO, M. M.; AKACHI, S.; OKANO, S.; YAMAMOTO, S.; HORIKAWA, K.; HARADA, S.; FUNATSUMARU, S.; OHNISHI, M. Molecular and serological investigation of Leptospira and leptospirosis in dogs in Japan. Journal of Medical Microbiology, v. 62, n. 4, p. 630-636, 2013. doi: 10.1099/jmm.0.050039-0.

LANGONI, H.; KURIBARA, I. Y.; FERREIRA, L. C. A. P.; ULLMANN, L. S.; SÁNCHEZ, G. P.; LUCHEIS, S. B. Antileptospirosis agglutinins in Brazilian capybaras (Hydrochoerus hydrochaeris). Journal of Venomous Animals and Toxins including Tropical Diseases, v. 22, n. 4, p. 1-4, 2016. doi: 10.1186/s40409-016-0059-6.

LANGONI, H.; SILVA, A. V.; SEGISMUNDO, R.; LUCHEIS, S. B.; PAES A. C. Epidemiological variables and clinical, haematological and urinary alterations in dogs seropositive for Leptospira spp. Semina: Ciências Agrárias, v. 34, n. 2, p. 765776, 2013. doi: 10.5433/1679-0359.2013v34n2p765.

LAVINSKY, M. O.; ABOU, R.; REUSS, G.; LANGONI, H. Seroprevalence of anti-Leptospira spp antibodies in Bahia, Brazil. Preventive Veterinary Medicine, v. 106, n. 1, p. 7984, 2012. doi: 10.1016/j.prevetmed.2012.03.015.

LOFFLER, S. G.; PAVAN, M. E.; VANASCO, B.; SAMARTINO, L.; SUAREZ, O.; AUTERI, C.; ROMERO, G.; BRIHUEGA, B. Genotypes of pathogenic Leptospira spp isolated from rodents in Argentina. Memórias do Instituto Oswaldo Cruz, v. 109, n. 2, p. 163-167, 2014. doi: 10.1590/0074-0276140295.

MINISTÉRIO DA SAÚDE (BRASIL); DATASUS. Sistema de informação de agravos de notificação: banco de dados, 2017. Available from: <https://bit.ly/2Db7bSd > Viewed: 03 set. 2017.

MIOTTO, B. A.; MORENO, L. Z.; GUILlOUX, A. G.; SOUSA, G. O.; LOUREIRO, A. P.; MORENO, A. M.; 
LILENBAUM, W.; VASCONCELLOS, S. A.; HEINEMANN, M. B.; HAGIWARA, M. K. Molecular and serological characterization of the first Leptospira santarosai strain isolated from a dog. Acta Tropica, v. 162, n. 1, p. 1-4, 2016. doi: 10.1016/j.actatropica.2016.06.007.

MWANGI, W.; FIGUEIREDO, P.; CRISCITIELLO, M. F. One health: addressing global challenges at the nexus of human, animal, and environmental health. PLoS Pathogens, v. 12, n. 9, p. 1-8, 2016. doi: 10.1371/journal.ppat.1005731.

PARAÍBA (Estado). Secretaria de Estado dos Recursos Hídricos, do Meio Ambiente e da Ciência e Tecnologia. Estudo para subsidiar a criação de unidade de conservação de proteção integral da mata do buraquinho - Paraíba. João Pessoa: Superintendência de Administração do Meio Ambiente, 2014. 134 p. Available from: <https://goo.gl/hdHA6c>. Viewed: 02 Dec. 2016.

PEREIRA, M. D. B. As chuvas na cidade de João Pessoa: uma abordagem genética. 2014. 93 f. Monografia (Bacharelado em Geografia) - Universidade Federal da Paraíba, João Pessoa, 2014.

PINTO, P. S.; LIBONATI, H.; LILENBAUM, W. A systematic review of leptospirosis on dogs, pigs, and horses in Latin America. Tropical Animal Health and Production, v. 49, n. 2, p. 231-238, 2017. doi: 10.1007/s11250-016-1201-8.

ROSSETTI, C. A.; LIEM, M.; SAMARTINO, L. E.; HARTSKEERL R. A. Buenos Aires, a new Leptospira serovar of serogroup Djasiman, isolated from an aborted dog fetus in Argentina. Veterinary Microbiology, v. 107, n. 3-4, p. 241248, 2005. doi: 10.1016/j.vetmic.2005.01.015.
SUEPAUL, S. M.; CARRINGTON, C. V.; CAMPBELL, M.; BORDE, G.; ADESIYUN, A. A. Serovars of Leptospira isolated from dogs and rodents. Epidemiology and Infection, v. 138, n. 7, p. 1059-1070, 2010. doi: $10.1017 /$ S0950268809990902.

THRUSFIELD, M. Epidemiologia veterinária. 2. ed. São Paulo: Roca, 2004. 556 p.

ULLMANN, L. S.; GUIMARÃES, F. F.; FORNAZARI, F.; TOMÉ, R. O.; CAMOSSI, L. G.; GRECA, H.; SILVA, R.; MENOZZI, B. D.; LANGONI, H. Ações de vigilância continuada, papel do cão como animal sentinela para toxoplasmose. Revista Brasileira Parasitologia Veterinária, v. 17, p. 345-347, 2008. Supplement 1.

VIEIRA, A. S.; NARDUCHE, L.; MARTINS, G.; SCHABIB PÉRES, I. A.; ZIMMERMANN, N. P.; JULIANO, R. S.; PELLEGRIN, A. O.; LILENBAUM W. Detection of wild animals as carriers of Leptospira by PCR in the Pantanal biome, Brazil. Acta Tropica, v. 163, p. 87-89, 2016. doi: 10.1016/j.actatropica.2016.08.001.

WORLD ORGANISATION FOR ANIMAL HEALTH (OIE). Reference laboratory reports activities. United Kingdom OIE. 2014. Available from: <https://goo.gl/ttvX8Q>. Viewed: 02 Aug 2016.

ZWIJNENBERG, R. J.; SMYTHE, L. D.; SYMONDS, M. I.; DOHNT, M. F.; TORIBIO, J. A. Cross-sectional study of canine leptospirosis in animal shelter populations in mainland Australia. Australian Veterinary Journal, v. 86, n. 8, p. 317-323, 2008. doi: 10.1111/j.1751-0813.2008.00324.x. 